\title{
KÜRESEL İKLİM DEĞİI̦íKLİĞİ BAĞLAMINDA YENİ TOPLUMSAL HAREKET ÖRNEĞİ OLARAK KÜRESEL ÇEVRECİ HAREKETLER
}

\author{
Dr. İbrahim MAVì \\ e-posta: ibrahimmavi01@gmail.com \\ ORCID 0000-0002-8268-6899
}

ÖZ

Küreselleşme, tüm dünyanın iletişim, teknoloji, bilimsel gelişmeler ve ulaşım aracılığıyla birbirini etkilediği bir süreci ifade etmektedir. Bu süreçte ulus devletler, terörizm, insan hakları, kültür, dil, savaș politikaları, ideolojiler, teknoloji, bilim, ekonomi, kimlik, çevre vb. alanlarda dönüşümler yaşanmıştır. Bu çalışmada toplumsal dönüşüm süreciyle ortaya çıkan yeni toplumsal hareketlerin küreselleşme ile olan ilişkisi irdelemektir. Çalışmanın önerisi yeni toplumsal hareketlerin klasik hareketlerden farklılaştı̆̆ı, barış, insan hakları, demokrasi, kimlik, yeni dini yönelimler, alternatif yaşam, cinsel özgürlük, cinsiyet, çevre vb. temalar bakımından klasik hareketlerden kopuş sağladığıdır. Ayrıca hareketlerin temaları, aktörleri ve taleplerinin değișmesiyle farklı hareket türleri ortaya çıkmıștır. Bu çalışmada yeni toplumsal hareketlerin bir örneği olarak çevre hareketleri ele alınmıştır. Çalışmanın amacı küreselleşmenin çevre üzerindeki olumsuz sonuçlarına odaklanan küresel çevre hareketlerinin ele aldığı, küresel ısınma, ekolojik kriz, çölleşme, orman yangınları, doğal kaynakların tahrip edilmesi, nükleer tehditler, yasadışı avlanma, hayvan türlerinin yok edilmesi vb. konuları çözümlemektir. Ayrıca çevre hareketlerinin bu alanlara yönelik alınan önlemlere öncülük ettiği, yeni dünyanın yeni aktörü olarak gelecekte de bu alana katkı sunacağı örneklerle savunulmaktadir.

Anahtar Kelimeler: Küreselleșme, Yeni Toplumsal Hareketler, Çevre Hareketleri, Küresel Isınma, İklim Krizi.

\section{GLOBAL ENVIRONMENTALIST MOVEMENTS AS AN EXAMPLE OF NEW SOCIAL MOVEMENTS IN THE CONTEXT OF GLOBAL CLIMATE CHANGE}

\begin{abstract}
Globalization refers to a process in which the whole world influences each other through communication, technology, scientific developments and transportation. In this process, nation states, terrorism, human rights, culture, language, war policies, ideologies, technology, scientific developments, economy, identity, environment, in short, the entire social structure has undergone a transformation. In this study, the relationship between the new social movements that emerged with the process of social transformation and globalization is to examine. The proposal of the study is that the new social movements differ from the classical movements, peace, human rights, democracy, identity, new religious orientations, alternative life, sexual freedom, gender, environment, etc. It is aimed that it provides a break from classical movements in terms of themes. In addition, different types of movements have emerged with the changes in the themes, actors and demands of the movements. In this study, environmental movements are discussed as an example of new social movements. The aim of the study is to deal with global environmental movements focusing on the negative consequences of globalization on the environment, global warming, ecological crisis, desertification, forest fires, destruction of natural resources, nuclear threats, illegal hunting, extinction of animal species, etc. to analyze the issues. In addition, it turns into the appearance of environmental movements in these areas, it is defended by considering the new world as a new playground.
\end{abstract}

Keywords: Globalization, New Social Movements, Environmental Movements, Global Warming, Climate Crisis.

Kaynak Gösterme: Mavi, İ., (2021). "Küresel İklim Değișikliği Bağlamında Yeni Toplumsal Hareket Örneği Olarak Küresel Çevreci Hareketler”. Nişantaşı Üniversitesi Sosyal Bilimler Dergisi, 2(9) 116-126. 


\section{GíRiş}

Küreselleșme, kimi zaman karșılıklı kimi zaman da tek taraflı mal ve hizmetlerde sınır ötesi ticareti, teknoloji ve yatırımı, insan ve bilgi akışlarının etkisiyle dünya ekonomilerinin, kültürlerinin ve nüfuslarının karşılıklı bağımlılıklarını ifade etmektedir. Küreselleșmeyi ortaya çıkaran karşılıklı ilişkilerin temeli yüzyıllar boyunca ülke ortaklıklarına ve ticari gelişmelere bağlı olsa da literatürde küreselleşmenin ilk süreci Soğuk Savaş dönemi olan 1960-1990 arasındaki iki kutuplu dünya süreci olarak kabul edilmektedir. İkinci süreç ise 1990'ların başındaki Soğuk Savaş'tan sonra, tek kutuplu dünya düzenidir ve en çok ilgiyi de bu dönemden itibaren görmüştür.

1990’lara kadar ekonomik, sosyal, kültürel, teknolojik bir dünya etkileşimini ifade eden küreselleşmenin tek kutuplu dünya ile kapitalizmin zaferini ilan etmesi bu süreci farklı boyutları ile ele almayı gerektirmiştir. Ekonomi, kültür, teknoloji, dil, siyaset, kimlik, cinsiyet, savaş ve barış, insan hakları, çevre vb. alanlar üzerinde etkili olan küreselleşmenin yarattığı olumsuzluklara karşı, yeni toplumsal hareket türleri ortaya çıkmıştır. Bu hareketlerden bazılarını sistem karşıtı, küreselleşme karşıtı şeklinde de adlandırmak mümkündür. Küreselleşme karşıtı yeni toplumsal hareketler küreselleşmenin olumsuzluklarına karşı çıkan politikalar geliştirmişlerdir.

Yeni toplumsal hareketler örneklerine bakıldığında küreselleşme karşıtı hareketler, sistem karşıtı hareketler, barış hareketleri, anti nükleer hareketler, kadın hareketleri, cinsel yönelimli hareketler, alternatif kimlik yönelimli hareketler, LGBT ve nihai olarak çevreci hareketler şeklinde sıralanabilir. Bu hareketlerin hepsi aktörleri ve vurguladıkları konular bakımından klasik hareketlerden farklılaşmaktadır. Yeni toplumsal hareketlerin hepsinin ortak vurgusu kimlik, ideal, yaşanabilir bir dünya iken, özelde de her hareketin üzerinde durduğu konu farklılaşmaktadır. Bu çalışmada da küreselleşmenin etkisiyle yaşanan iklim değişikliklerine, küresel ısınmaya ve iklim krizine dikkat çeken çevreci hareketler ele alınmaktadır. Tüm dünyayı etkilemeye başlayan küresel ısınmanın sebepleri, çölleşme ve doğal kaynakların zarar görmesi, orman yangınları, dünyanın birçok yerinde yaşanan su, hava ve toprak kirliliği, deniz ve okyanusların zarar görmesi sonucu canlı türlerinin yok olması gibi çevre tahribatlarına odaklanan çevreci hareketler, yeni dünya düzeninin temel aktörleri haline gelmiştir. Bu aktörler aynı zamanda küresel sorunlara yönelik devletlerin yeterli önlemleri almamalarının sebepleri üzerinde durmaktadır.

Küresel dönemde ekonomik sebeplerle de bağlantılı olan ve karmaşık bir ilişki ağı bulunan çevre sorunlarına yönelik birçok devlet ve sivil toplum kuruluşu harekete geçmiştir. Fakat Birleşmiş Milletler, Avrupa Birliği ülkeleri ile diğer gelişmiş ülkeler tarafından çevre sorunlarına yönelik yeterli önlemin alınmaması nedeniyle küreselleşme döneminde dünyadaki bütün çevre hareketleri küresel ısınma ve iklim değişikliği konularına değinmektedirler. Bu küresel hareketlere göre, dünyadaki ekolojik sorunlar sınır dinlemezler ve insanlar değişik ülkelerde yaşasalar da gezegende yaşanan her çevre olayından etkileneceklerdir. Bu nedenle sorunlar evrenseldir. Çevreci hareketlere göre küresel ısınma ve iklim değişikliği ortak bir tehlikedir ve bu ortak tehlike karşısında izlenecek politikalar da küresel boyutta olmalıdır.

Bu çalıșma yeni toplumsal hareketlerin bir örneği olan çevreci hareketlerin küresel boyutta etkili olan politikalara nasıl etki ettiğini çözümlemektedir. Ayrıca farklı temalar etrafında ortaya çıkan yeni toplumsal hareketler, küreselleşme çağının ortaya çıkardığı olumsuzluklara karşı çeşitli şekillerde örgütlenmiştir. Çalışmamızın temel amacı yeni toplumsal hareketlerin bir örneği olan ve küreselleşmenin çevre üzerindeki olumsuzluklarına odaklanan yeni ekolojik yönelimler ile çevre hareketlerinin bu örgütlülüğü nasıl sağladığı ve devlet politikaları üzerinde de ne kadar etkili olduğunu açıklamaktır. Ayrıca küresel iklim değişikliği önlemlerinin alınmasında devlet politikaları üzerindeki etkisinin yanı sıra, toplumsal bir bilinç ve farkındalık yaratmadaki rolleri de incelenmektedir. 


\section{Küreselleşme Döneminde Yeni Toplumsal Hareketler}

Küreselleşme çok boyutlu bir sistemi ifade etmektedir. Marshall Mcluhan'ın Global Village (Küresel Köy) (2001) olarak tanımladığı küreselleşme, sınırların ortadan kalkması ve toplumların kısa sürede birbirini etkilemesi sürecini ifade etmektedir. Soğuk Savaş dönemindeki gelişmeler ışığında 1960'lı yıllar ve sonrasında etkisini daha fazla göstermeye başlayan küreselleşmeyi çeşitli şekillerde tanımlamak mümkündür. Giddens (1998: 61-63) küreselleşmeyi kapitalizm, ulus devlet, askeri dünya düzeni ve uluslararası iş bölümü boyutlarıyla ele alıp modernliğin bir sonucu olduğunu vurgularken, Robertson (1999: 21), dünyanın tek bir çatı altında birleşmesi, Bauman (2017: 75) yeni dünya düzensizliği, Chomsky (2002: 84) yeni şekliyle Neo Liberalizm, Wallerstein (2009: 16), kapitalizmin yeni versiyonu olması açısından yeni dünya düzeni şeklinde bir tanıma başvurmuştur. Touraine (2007: 287) küreselleşmeyi, uç noktada bir kapitalizm biçimi olarak, ekonomi ile artık onu denetleyemeyen kurumların, hatta başta toplumsal ve siyasal olanların birbirinden bütünüyle ayrılması şeklinde ifade etmiştir.

Küreselleşme ilk olarak ekonomi alanında başlasa da bu süreç yakın dönemde kültür alanına yansımış, tüketim, fastfood, sinema kültürü, kitle iletişim araçları, medyanın gelişmesi, neo liberal politikalarla yayılma alanı bulan kapitalizmin etkisiyle üst boyuta ulaşmıştır. $\mathrm{Bu}$ boyutuyla toplumsal hareketler üzerinde de etkili olmuştur. Modernleşmenin bir uzantısı olarak görülen (Kömeçoğlu, 2002: 12) küreselleşme, teknik ve bilimsel alanda meydana gelen ilerleme, gelişme ve büyüme fikrine öncülük etmiştir. bu ilerleme fikri sonucunda teknoloji gelişmiş, sanayi büyümüş, küresel ekonomiye sahip şirketlerin sayısı artmıştır. Küresel şirketlerin artmasıyla sosyo-ekonomik bir sistemin yarattığı yapısal sorunların egemenliği altındaki bir dönemden çıkıp kapitalizmin, dolayısıyla da tarihsel değişimin belli bir yönetim şeklinin, belli bir modernleşme şeklinin utkusunun temel yeri tuttuğu bir evreye (Touraine, 2007: 45) geçilmiştir.

Modernliğin gelişim ve değişim sürecinden yola çlkarak vurgulamak gerekirse, küreselleşme geri dönülemez bir süreç olarak toplumsal hareketler üzerinde etkili olmuş, küresel toplumsal hareket dönüşümüne öncülük etmiştir. Çünkü coğrafi sınırların daralması, iletişim teknolojilerinin gelişimi, çağdaşlaşma, sermayenin, mal ve hizmetlerin serbest dolaşımı, farklı kültürlerin birbirinden haberdar olması, dünya siyasal sınırların, kalkmasa bile belirsizleşmesi ve tüketim kültürünü ortak bir noktada buluşturma (Durul, 2008: 21) bu süreci hızlandırmıștır.

Küreselleşmenin toplumsal alanda yarattığı hızlı dönüşüm toplumsal hareketlerde de ortaya çıkmıştır. Bu hızlı değişim süreciyle daha önce Marksizm'in sınıf hareketleri şeklinde ele aldığı klasik hareketlerden yeni toplumsal hareketlere geçilmiştir. Bunun sebebi klasik teorilerin yeni toplumsal konuları açıklamadaki yetersizlikleri olarak görülmektedir. Çünkü toplumsal hareketleri farklı boyutları ile ele alan akademik çevrelerin eksik bıraktığı alanlardan biri yeni toplumsal alanlar olmuştur. 1960'lı yıllar ve sonrasında Amerika'da ekonomik temelli, Avrupa'da ise kimlik temelli ortaya çıkan hareketler, yeni dünyanın yeni sorunlarına odaklanmışlardır. Çevre, kimlik, barış, insan hakları, alternatif yaşam ve cinsel özgürlük hareketleri şeklinde ortaya çıkan yeni toplumsal hareketler, "küreselleșen dünyada yeni kimlik arayışlarını ifade eden" (Çayır, 2016: 8) topluluklar şeklinde yeni eylem biçimlerine başvurmuştur. Yeni protesto hareketleri, yeni politikalar, yeni popülizm, neoromantizm, antipolitik, Ortodoks olmayan siyasal davranış ve düzensiz politikalar (Offe, 2016: 54) gibi adlandırmalarla ortaya çıkan yeni toplumsal harekelerin ilgi alanı, ekoloji ya da çevre, insan hakları, kadın hareketleri, toplumsal cinsiyet, cinsiyet ayrımı olmadan her alanda eşit katılım, pasifizm, barış, gelir adaleti vb. konular olmuştur.

1990’lara kadar soğuk savaş politikaları çerçevesinde gelişme gösteren yeni toplumsal hareketler, küreselleşmenin bir sonucu olarak tek kutuplu dünyanın zaferini ilan etmesiyle dönüşüm yaşamıştır. Küreselleşme ile bağlantılı olarak günümüzün temel sorunlarına değinen yeni toplumsal hareketler 1990'lardan itibaren yeniden şekillenerek, sistem karşıtı veya küreselleşme karşıtı, küresel adalet hareketi, yeni ekolojik hareketler şeklinde kamusal alanda daha fazla görünür olmuștur. Küresel gelişmeler bağlamında ortaya çıkan normlara karşı bir bilinç geliştirmeyi amaçlayan yeni toplumsal hareketler (Dede, 2018: 165-166) 
küresel sorunlar çerçevesinde ortak bir amaca kilitlenmişlerdir. Bu amaç doğrultusunda da dünyanın birçok kentinde örgütlenmeler sağlanmış, dünyanın ortak sorunlarına tepkiler oluşmuştur. Bu tepkiler çeşitlilik göstermekle beraber, Brezilya'da 1992 yılında gerçekleştirilen Dünya Forumu, Hindistan'da 1993 yılında Dünya Ticaret Örgütünün (WTO) görüşmeleri esnasında ortaya çıkan kitlesel tepkiler, 1994 yılında Chiapas'ta Zapatistaların NAFTA'ya* karşı eylem ve tepkileri, 1997 yılında G7 zirvesine karşı ayaklanan kitleler ve nihai olarak küresel ekonomik örgütlenmelerine karşı oluşmaya başlayan büyük kitlelerin eylemleri (Wall Stret İşgali vb.) dünya çapındaki yeni sosyal hareket örnekleridir. Dünya Sosyal Forumları'nın gün geçtikçe artması, IMF ve Dünya Bankasına (WB) karşı yapılan eylemler küresel hareketlerin etkisini artırdığının göstergesi olmuştur.

Küresel yeni toplumsal hareketlerin neredeyse tamamı küreselleşme ve onun yarattı̆̆ olumsuzluklara odaklanmışlardır. Nitekim küresel eylemlerin ortaya çıkışının temel sebebi Wallerstein (2009: 11) tarafından "tarihsel bir toplumsal sistem olan kapitalizmin" neoliberal ekonomik politikaların desteğiyle küreselleşen dünyada ortaya çıkardığı sorunlar şeklinde vurgulanmıştır. Topyekûn bir küreselleşme karşıtlığından çok küreselleşmenin olumsuz sonuçlarına ve ortaya çıkardığı sorunlara odaklanan hareketler küresel dünyanın yeni aktörleri olmuştur. 1999'da Seattle'da yapılan Dünya Ticaret Örgütü (DTÖ) zirvesine karşı eylem, ardından IMF ve WB gibi küresel ekonomik kuruluşlara karşı devam eden kitlesel eylemler, Seattle (70 bin), Nice (100 bin) ve Cenova'da (300 bin) gerçekleştirilen (Aslan, 2016: 154) büyük katılımlı protestolar, BM İklim Konferans protestoları küresel olumsuzlukların kaynaklarına değinmişlerdir.

Küresel olumsuzluklara değinen yeni toplumsal hareketler için küreselleşme karşıtlığı kavramına başvuran Touraine'a (2007: 44) göre, küreselleşme karşıtlı̆̆ı genel teması çerçevesinde, bir başkadünya projesinde buluşan ve yukarıda vurgulanan hareketlerin çok çeşitli talepleri söz konusu olmuştur. Touraine'a göre, Porto Alegre Forum'unun başarısı, Seattle, Göteborg, Cenova bildirgelerine ve her şeyden önce eleştirel bir işlev taşıyan diğer birçok bildirgeye olumlu bir anlam kazandırmaya yönelik toplumsal hareketleri ve düşünce akımlarını bir araya toplamaya çalışmış olması bakımından küreselleşme karşıtı hareketler ilerleme kaydetmiștir. Küresel ekonominin en önemli yöneticilerine meydan okumak, çeşitli olduğu kadar güçlü de olan bir hareket düzenlemek bu ilerlemelerin başında gelmiştir.

Dünya üzerinde değişen doğal şartların daha kötüye gittiğine inanarak bu alanlarda iyileştirme için bir şeyler yapılması gerektiği düşüncesinden hareket eden çevre hareketi (Uysal, 2016: 152), özellikle son dönemlerde artan iklim değişikliğine paralel olarak, kuraklık, buzulların erimesi, çölleşme, denizlerin ve ormanların tahrip edilmesi, biyolojik çeşitliliğin azalması, asit yağmurları, ozon tabakasının delinmesine neden olan sera gazlarının yayılımı, hava, su ve toprak kirliliği, nükleer tehditler, deniz ve okyanus kirliliğinden dolayı canlıların etkilenmesi, doğal kaynakların zarar görmesi vb. konular üzerinde durmuşlardır. $\mathrm{Bu}$ konuların hepsinin küreselleşme politikalarıyla bağlantılı olduğu da ayrıca vurgulanmıştır.

\section{Küreselleşen Dünyada Çevre Sorunları: İklim Değişikliği Küresel Isınma ve Çözüm Arayışları}

Küreselleşme sonucu ortaya çıkan ilerleme fikri, teknolojik gelişmelere öncülük etmiştir. Bu teknolojik gelişmeler sadece toplumsal yarar gözeten bilimsel gelişmelere değil, aynı zamanda küresel savaşlara, nükleer silah yapımlarına, kitle imha silahlarına da öncülük etmiştir. Aynı şekilde üretim sürecinde devasa fabrikaların gelişmesine, sanayinin de giderek geniş alana yayılmasına öncülük etmiştir. Bu teknolojik gelişmeler sonucunda dünyadaki hava dengesinin de bozulması kaçınılmaz olmuştur. Sanayinin gelişmeye başladığı 19. yüzyıl ve sonrasında insan kaynaklı sera gazı yoğunluğunun artması bu hava kirliliği örneğinin başında gelmektedir. Bu yoğunluk gün geçtikçe de artmaya, küresel ısınma ve iklim değişikliği yaratmaya devam etmektedir. Bunun sonucunda da buzullar erimekte, dünya genelinde mevsim değişiklikleri yaşanmaktadır. Bu iklim değişikliğine bağlı olarak da canlı türleri gün geçtikçe olumsuzluklara maruz kalmaktadır. Bu olumsuzluklar iklimin doğal bir

\footnotetext{
* Kuzey Amerika Serbest Ticaret Anlaşması; Kanada, ABD ve Meksika devletlerinin 1989'da kurdukları ticari ve ekonomik birlik.
} 
sonucu değil, insan eliyle oluşturulan bir dünyanın yapay sorunlarıdır. Bu sorunlar geri dönülmez bir şekilde küresel bir hal almıştır.

Dünyanın herhangi bir yerinde yaşanan çevre kirliliği veya iklim tehdidi artık sadece o ülke için değil tüm dünya için bir tehdit haline gelmiştir. Keskin'e (2003: 103) göre içinde bulunduğumuz küresel ekolojik krizi yaratan endüstrileşmiş ülkeler, artık gezegenin tümünü tehdit eden yaşam biçimlerini ve yıkıcı politikalarını sürdürmek adına, tehlikeli atıklarını, kirli, riskli, eski teknolojilerini en yoksul ve savunmasız olan ülkelere aktarıyor. Artık şirketlerin insanlardan daha fazla hakları var, birçok ülkeyi satın alabilecek kadar varlıklılar, her düzeyde politikacılar onlara hizmet ediyor, bunların sonucunda da yıkıcı etkinliklerinin hesabını vermeme, bunlardan sorumlu tutulma gibi ayrıcalıklara sahip duruma gelmişlerdir. $\mathrm{Bu}$ keyfi uygulamalar sonucu çevre sorunları gün geçtikçe artmıştır.

Keyfi uygulamalar ve küresel ekonominin kâr hırsından dolayı artan küresel çevre sorunları etkisini göstermeye başlayınca, çevre sorunlarının sadece çevre ile ilgili olmadığı, ekonomik, siyasi ve kültürel bazı karmaşık ilişkilerle bağlantılı olduğu, bu sorunların önlenmesi için yasal düzenlemelere de ihtiyaç duyulduğu anlaşılmıştır. Bu ilişkiyi ele alan BM İkinci Dünya Savaşı sonrasında insan haklarına dair bazı gelişmelere öncülük edip yasal düzenlemeler yaparken, çevreyi korumaya yönelik politikalar da geliştirmişlerdir. Gerek devletler gerek sivil toplum kuruluşları ve çevreci hareketler tarafından vurgulanan çevre sorunları 1960'lı yıllardan sonra uluslararası bir gündem haline gelmiştir.

Uluslararası gündem haline gelen gelişmelerin ilk örneği 1972 yılında gerçekleşmiştir. İnsan ve Çevre Konferansı'yla dünyanın gelişme süreci ile kalkınmasının aslında çevre ile bağlantılı olduğu (Kalouche ve Mielants, 2008: 268) anlaşılmıştır. Bunun sonucunda da çevre sorunlarına karşı alınacak önlemler görüşülmeye başlanmıştır. Çünkü çevre sorunları gün geçtikçe artmaktadır. Bu sorunlara değinen birçok çalışma yapılmıştır ki bunlardan biri Brundtland Raporu'dur. Küresel sorunları ortaya koyarak, "Ortak Geleceğimiz" temasıyla hazırlanan Brundtland Raporu, 1987 yılında Dünya Çevre ve Kalkınma Komisyonu tarafından hazırlanmıştır. $\mathrm{Bu}$ rapora göre, acil alınması gereken önlemler söz konusudur. Çevre sorunlarının giderek arttı̆̆ bir dünyada alınacak önlemler üzerinde uzlaşma sağlanamamış, artan çevre sorunları nedeniyle 1990 ve sonrasinda bu önlemlere daha fazla ihtiyaç duyulmuştur. Çünkü küreselleşmenin en üst boyutu 1990 ve sonrasında yaşanmaya başlanmıştır. Küresel kapitalist politikaların yarattığı çevre sorunlarına yönelik önlemlerin aciliyetinin anlaşılması üzerine, 1992 yılında Rio'da Birleşmiş Milletler Çevre ve Kalkınma Konferansı gerçekleştirilmiştir. 2000 yılından itibaren de BM tarafından tertip edilen Binyıl Zirvesi, BM Sürdürülebilir Kalkınma Zirvesi” gibi gelişmeler çevre sorunları için önemli adımlar olmuştur. Bu çalışmaların hepsinin amacı küresel çevre sorunlarına dair ortak çözüm arayışları olmuştur.

İklim değişikliğinin ciddi sorunlara neden olması ve tüm dünyayı etkilemesi nedeniyle ortak çözüm oluşturmaya çalışan BM, AB, OECD, AGİT gibi uluslararası kuruluşlar radikal önlemlerin alınması gerektiğine dair tepkilerle karşılașmıştır. Nitekim dünyanın bir bütün halinde küresel çevre sorunlarından etkilenmeye başlaması da bunun en büyük sebebi olmuştur. $\mathrm{Bu}$ amaçla gerçekleştirilen "Ozon Tabakasının Korunmasına Dair Viyana Sözleşmesi", "BM İklim Değişikliği Çerçeve Sözleşmesi", "BM Biyolojik Çeşitlilik Sözleşmesi" ve "BM Çölleşme ile Mücadele Sözleşmesi" küresel çözüm arayışının önemli adımları olmuştur.

Küresel politikalarla çevre sorunlarına çözüm üretmeye çalışan uluslararası kuruluşlar, BM, $\mathrm{AB}$ gibi örgütlerin tüm çalışmalarına rağmen dünyada çevre sorunları yaşanmaya, küresel iklim değişmeye devam etmiştir. Çevre sorunlarının yaşanmasında küresel şirketlerin ve küresel finans kuruluşlarının etkisi azımsanmayacak derecede büyüktür. Bu kuruluşların başında gelen IMF, DB, DTÖ gibi uluslararası finans ve ekonomi kuruluşları, neo-liberal kapitalist gelişme modelini geliştirmeye öncülük ederek, liberal politikaların Batı Avrupa'da gelişmesini sağlamıştır. 1989'da Doğu Bloku'nun çöküşüyle geri kalan ülkeleri de etkisi altına almıştır. Tüm dünyayı etkisi altına almaya çalışan neo-liberal kapitalist gelişme modelinin temel amacı bütün ülkeleri benzer siyasi ve sosyo-ekonomik çatı altında toplamak olmuştur. Bunu sağlamak için de birçok ülkeye avantajlı ve cazip koşullar sunduktan sonra, ülkenin 
temel kaynaklarını, devlet işletmelerine ait olan kurumları, tüm dünya için hayati öneme sahip olan su, orman, toprak ve araziler ile sosyal güvenlik, eğitim, sağlık gibi temel insan haklarını özelleștirme yoluna gidilmiștir. Bu özelleștirme politikasıyla başlayan daha fazla kâr hırsı çevre tahribatlarını gün geçtikçe artırmaya devam etmektedir.

\section{Küreselleşme Sürecinde Yeni Çevre Hareketleri}

Yeni eylem biçimleriyle küresel olumsuzluklara odaklanan çevre hareketleri küresel bir nitelik kazanmıştır. Bu niteliğiyle yeni çevre hareketlerini incelerken öncelikle kavramsal kargaşanın da giderilmesi gerekmektedir. Çünkü çevre ile ilgili birçok kavram söz konusudur ve bu kavramlar genellikle birbirinden farklı anlamlar ifade edebilmektedir. Bu farklılıkların iyi tanımlanması konumuz açısından olduğu kadar hareketlerle ilgili kargaşanın ortadan kaldırılması açısından da önemlidir. Özellikle de çevre hareketi ve ekolojizmin çevrecilik bağlamında farklı şekillerde ele alınması, bu kargaşayı ortaya çıkarmıştır. Bu kargaşanın önüne geçmek için ekolojizm ve çevrecilik kavramlarını ayırmak gerekmektedir. Siyasal ve toplumsal bağlamlarda değerlendirilen çevrecilik (environmentalism) ve ekolojizmin (ecologism) düşünsel olarak farklı yönelimlere sahip olduğunu vurgulayan Castells'e (2010: 170) göre, çevre hareketlerinin temel amacı, egemen güçlerin veya egemen kurumların insanlar için hayati önem taşıyan çevreye verdikleri zararı ortaya çıkarmak ve önlemektir. Ekolojizm ise ekosistem üzerine odaklanarak, insanların da bu sistemin bir parçası olduğunu, burada bir evrimin de devam ettiğini ve bu açıdan sistemin dinamik bir sürecin ifadesi olduğunu vurgulamaktadır. Bu süreçte temel amaç sistemi korumaktır. İki kavram arasındaki temel farkı vurgulayan Castells'e göre "çevrecilik pratikteki ekoloji, ekoloji de kuramdaki çevreciliktir." Bu açıdan pratikteki ekoloji olan çevre hareketleri konunun ana temasını oluşturmaktadır.

Küreselleşme etkisiyle bir dönüşüm yaşayan ve eylem pratikleriyle ortaya çıkan çevre hareketleri, hayvansever ya da doğasever özelliklerinden ziyade daha radikal eylemlere başvurup, yeni konulara odaklanmışlardır. Bu konuların başında zehirli olan ve kanserojen etkiye sahip atıklara karşı tepki gösterileri, tüketici haklarını savunma, anti-nükleer protestolar, eko-feminizm gelmektedir. Bu yaklaşımlar çerçevesinde, çevre sorunlarının ortaya çıkmasının en büyük sebebinin doğanın bir bütün olarak metalaştırılması olduğunu vurgulayan çevre hareketleri, devletten ve devlet bloklarından doğan bir boşluktan dolayı 1990'lardan itibaren daha fazla etkili olmaya başlamıştır. Çeşitli eylem pratikleriyle ortaya çıkan çevreci hareketler, doğanın tamamının paraya dönüştürülmesine tepki niteliğinde eylemler gerçekleştirmiştir. Eylem biçimleriyle küresel bir harekete dönüşmüş olan, birçok konuda da "derin yeşil" bir hareket" (Kalouche ve Mielants, 2008: 268) özelliği kazanan çevre hareketleri artan küresel sorunlar için kulisler oluşturmuştur. Uluslararası örgütlenme sağlayan ve yerellerde olduğu kadar küresel sorunlara da değinen küresel çevre hareketleri, devletlerin kısa sürede çözemediği sorunlara değinmeleri ve kısa sürede çözüme katkı sunmaları bakımından önemli bir aktör haline gelmiștir.

Küresel sorunlara çözüm bulmaya çalışan yeni toplumsal hareketler, eylem biçimleri, aktörleri ve vurguladıkları konular bakımından toplumsal muhalefet görevi görmeye başlamıştır. Bu misyonla küreselleşmenin olumsuz sonuçlarına karşı çıkmıştır. Bu olumsuz sonuçlardan biri olarak görülmeye başlayan iklim değişikliği, küresel ısınma ve iklim krizi, yeni toplumsal hareketlerin bir örneği olan çevreci hareketler tarafından ele alınmıştır. Küresel iklim krizinin ortaya çıkmasıyla, küresel ısınma sonucu iklimde yaşanan değişimlerin insan kaynaklı sonuçlarına yönelen ekolojik yönelimler, dünyamızın kirletilmesine, buzulların erimesine, hayvanların ve doğanın hırs uğruna tahrip edilmesine karşı çıkmışlardır.

Çevre hareketlerinin savaşım alanı çevre tahribatlarıdır. Bu tahribatlara karşı da farklı hareket biçimleri ortaya çıkmıştır. Giddens'a (1998: 158) göre, günümüzün "yeşil hareketleri" şeklinde de örgütlenen bu hareketler, ekolojik kaygılara odaklanmaktadır. Ekolojik kaygıların yalnızca yüksek etkili risklerden kaynaklanmayıp, yaratılmış çevrenin diğer yönleri üzerine de odaklan çevreci hareketler, çevre sorunlarının diğer toplumsal sorunlarla da ilgili olduğunu vurgulamaktadırlar. Bu açıdan Galtung'a (2013: 176) göre, ekolojik bozulma sorununu yalnızca çevreyi kirletenler ve tüketenler bakımından açıklayabilseydik; 
"sürdürülebilir gelişme" kavramıyla uyumlu olarak çevrenin kirletilmesi ve tüketilmesi için evrensel üst sınırları belirleyen üst normlar oluşturabilseydik; bu normların ihlalini saptayacak bir dünya tespit sistemi örgütleyebilseydik; bunları ihlal edenleri bir dünya mahkemesine (örneğin uluslararası adalet divanı) verebilseydik ve çevreyi kirletenlerin (ve tüketenlerin) verdikleri zararı ödemelerini, hatta hapse girmelerini sağlayabilseydik her şey ne kadar basit olurdu. Toplumsal kötülükler kötü edimler çerçevesinde kavranır, kötü edimlerin ardındaki kötü failler tespit edilir ve bu kötü tavırlarını değiştirmelerini sağlamak ya da en azından benzer kötü niyetleri olan başka faillerin gözünü korkutma amacıyla tanımlanır ve cezalandırabilirdik. Fakat böylesi bir durum mümkün görülmemektedir ki bunun en büyük sebebi küresel egemen güçler ile küresel şirketlerin izledikleri politikalardır.

Küresel güçlerin ve devlet bloklarının yukarıda bahsedilen sorunlara karşın çevreyi koruma ve ekolojik sorunları tamamen ortadan kaldırma kaygılarının olmaması nedeniyle küresel çevre hareketleri geniş bir alana yayılmıștır. Aktörleri orta sınıf, aydın ve öğrencilerden oluşan, siyasal bir ideolojiye hizmet etmeyen ve şiddet dışı eylemlere başvuran yeni çevre hareketleri, Greenpeace ve Earth First! örneklerinde görüldüğü gibi, dünya küresel sistemine karşı çıkarak, doğanın amaçlar uğruna sömürülmesine müsaade etmeyen sistem karşıtı hareketler (Kalouche ve Mielants, 2008: 243) haline gelmiştir. Ayrıca Avrupa'nın birçok ülkesinde çevre hareketi ile ortak amaçlara sahip olan Yeşiller Partisi de önemli gelişmelere zemin hazırlamış ve bu alanda başarılı olmuştur (Uysal, 2016: 153). Bu örneklerden anlaşıldığı üzere çevre ile ilgili olarak hareket alanı çeşitlilik kazanmıştır. Bu çeşitliliğin anlaşılması için Tablo-1'i detaylı bir şekilde incelemek gerekmektedir.

Tablo 1. Çevre Hareketlerinin Tipolojisi

\begin{tabular}{|c|c|c|c|}
\hline ÖRNEK & ÜYELERİ & KARŞI OLUNANLAR & AMAÇ \\
\hline $\begin{array}{l}\text { Doğa Koruma (Grup } \\
\text { Ten, Amerika) }\end{array}$ & Doğa ıșıkları & Kontrolsüz gelişme & Vahşi doğa \\
\hline $\begin{array}{l}\text { Kendi alanın korunması } \\
\text { (Not in my Back Yard) }\end{array}$ & Yerel Komünite & Kirleticiler & Yaşam kalitesi \\
\hline $\begin{array}{c}\text { Alternatif kültür, Derin } \\
\text { ekoloji } \\
\text { (Earth first ve } \\
\text { Ekofeminizm) }\end{array}$ & Yeşil Bireyler & $\begin{array}{c}\text { Endüstrilerşme, } \\
\text { Teknokrasi ve Ataerkil } \\
\text { toplum }\end{array}$ & Ekoütopya \\
\hline $\begin{array}{c}\text { Dünyayı kurtarın } \\
\text { (Greenpeace) }\end{array}$ & $\begin{array}{l}\text { Uluslararası ekoloji- } \\
\text { savaşçıları }\end{array}$ & Olumlu küresel gelişme & Sürdürlebilirlik \\
\hline $\begin{array}{l}\text { Yeşil Politika } \\
\text { (Die Grünen) }\end{array}$ & İlgili vatandaşlar & Politik kurum & Alternatif güç \\
\hline
\end{tabular}

Kaynak: yeșilgazete.org- Ebru Bingöl

Tablo 1'de ele alınan hareketler içerisinde küresel çevre sorunlarına dikkat çeken ve dünya çapında etkili olan çevre hareketinin bir örneği olarak Greenpeace hareketi etkili hareketler içinde yer almaktadır. 24 ulusal ve 4 bölgesel olmak üzere 40 ofisi, 101 ülkede 3 milyondan fazla destekçisi bulunan Greenpeace uzun yıllardır mücadele vermektedir. İlk mücadeleleri 1971 yılında Alaska'nın doğusunda atom bombası denemeleri yapan ABD'nin silahlanmasına ve denemeler yaparak doğaya zarar vermesine karşı çıkmak olmuştur (Keskin, 2003: 99). Aynı kararlılığı Fransa'nın nükleer denemelerine, Sovyetler ve Japonya'nın soykırıma dönüşen ticari balina avcılığına, Norveçliler'in yavru fok katliamına karşı çıkarak sürdüren Greenpeace, ilk eylem ve çalışmaların ardından, ideallerinden ödün vermeyen, değişime 
inanan çok sayıda insanın bir araya gelmesi, küreselleşmenin olumlu katkıları sonucunda günümüze kadar gelişme göstermiştir.

Çevre duyarlılığına dair başlayan hareketlerden Greenpeace'ın yanı sıra, dünya çapındaki en geniş katılımlı örneklerinden biri 1970'de 20 milyon insan ile Earth Day'de olmuştur. Ardından Earth First çevreci girişiminin 1980'lerden itibaren farkındalık yaratmasıyla çevresel girişim örnekleri daha sonraki yıllarda artmıştır. Siyasal alanda hükümet politikaları üzerinde etkili olan Yeşiller Partisi vb. hareketler de ilk çevre duyarlılıklarının önünü açmışlardır. 2018 yılında Greta Thunberg isimli bir öğrenci tarafından başlatılan ve küresel bir hal almış Friday For Future (iklim için okul eylemi) (Mavi, 2021: 222) çevre duyarlılığının artmasında etkili olan popüler hareketler içinde yer almıştır. Bu hareketin savunucularına göre dünya çevre tahribatları artmıştır ve bu tahribatların telafisi tamamen mümkün olmasa da alınacak güçlü siyasal önlemler sonucunda bundan sonraki dünya sorunları engellenebilir (Onbaşı, 2019: 22).

Çevre duyarlılığı sadece deniz, okyanus, ormanlarla sınırlı değildir. Aynı şekilde diğer canlı türleri için harcanan çaba da bu kapsamda değerlendirilebilir. Greenpeace gibi çevre sorunlarına karşı örgütlenen hareketler, aynı kapsamda yer alabilecek hayvan hakları hareketleriyle ortak eylemlere başvurmuşlardır. Daha önce de vurguladığımız gibi çevre sorunları karmaşık bir ilişkiyi kapsamaktadır. Bu nedenle tüm canlı türleri ile ilgili olan çevre hareketleri hayvan haklarının da bu kapsamda değerlendirmesini yapmışlardır. Bu kapsamda gelişme gösteren çevreci hareketler içerisindeki radikal öğelerin büyümesi 1990'da binlerce hayvan hakları aktivistinin Washington'da Hayvan Hakları Yürüyüşü için bir araya gelmesiyle (Kalouche ve Mielants, 2008: 268) etkili olmuştur. Ardından People for Ethical Treatment of Animals (PETA) üyelerinin "Yeşil Devrim" döneminde üç yüz bine ulaşması bu sürecin destek gördüğ̈̈nün kanıtı olmuştur.

Earth First! gibi "ekolojik direniş hareketleri”, eko feminizm, PETA ve ardından küresel ekolojik hareketler çevre farkındalı̆̆ı kadar hayvan haklarını da vurgulayan hareketler olmuştur. Bu hareketlerin temel gayesi insan özne olamayan çevre ve hayvanların da temel haklara sahip olmasını sağlamaktır. Bu nedenle çevrecilerin ve hayvan özgürleşmesinden yana olanların ileri sürdükleri üzere, eğer hak ve hukuki koruma sağlanacak olursa onların hukuki özneler haline gelmelerinin önünde hiçbir engel yoktur (Douzinas, 2017: 402). Bu nedenle bu gezegende yașayan insanların haklarına duyulan saygının ve gösterilen özenin diğer canlı türleri için de gösterilmesi gerekmektedir. Nihai noktada küresel çevre sorunları insan sağlığı ve güvenliği kadar diğer canlı türleri üzerinde de etkili olmaktadır.

Küresel çevre hareketlerinin hepsi çağımızın temel sorunu olan ikim krizine odaklanırken, iklimin tüm canlılar için önemini vurgulayarak, buzulların, okyanusların, deniz ve ormanların zarar görmesinin sonuçları kadar nedenleri üzerinde de durmuşlardır. İklim değişikliğine ve çevre sorunlarına değinen hareketlere göre, iklim krizine neden olan en büyük etken küresel sermaye ve onların temsilcileri olan küresel güçlerdir. Ulus aşırı sermaye tüm dünyada ölçülemeyecek kadar büyük kârların küçük bir azınlığın eline geçtiği dev bir piyasa yaratmakta, çoğunluğu sefalete ve umutsuzluğa sürüklemekte, geleneksel toplumları dünya yüzünden silmekte ve biyosferi zehirlemektedir (Bıehl, 2016: 9). Bu zehir dünya iklimini değiștirirken, kuraklığa neden olmakta, son dönemde tüm dünyada etkisini daha fazla göstermeye başlayan orman yangınlarını artırmaktadır. En büyük örneklerden biri de 20192020 yılları arasında yaklaşık olarak 240 gün süren Avustralya orman yangınlarıdır. Yangın sonucu 8 milyon hektar ormanın yanması ve tahmini olarak 1,1 milyardan fazla hayvanın ölmesi(Theguardian, 01.01.2020). küresel iklim sorununa bir örnektir. Aynı şekilde İtalya, Yunanistan, Arnavutluk, İspanya, Fransa, Romanya ve Rusya'da 2021 yllında artan orman yangınları, yakın dönemde Türkiye'de de 35 ilde 129 yangın olayının yaşanması, Manavgat, Marmaris, Bodrum başta olmak üzere binlerce hektar ormanın yanması, yerleşim yerlerinin bu durumdan etkilenmesi yine küresel iklim sorunları bağlamında ele alınabilir.

Küresel ısınma ve doğa üzerindeki etkisi, çevre güvenliğini tehdit ederken, aynı zamanda insani güvenlik sorununu da ortaya çıkarmıştır. Çağımızın en büyük sorunları içerisinde yer almaya başlayan çevre sorunlarının hafife alınmaması için tüm dünyanın sorumluluk alması gerekmektedir. Fakat bu sorumlulukların yerine getirilmemesi nedeniyle yeni toplumsal 
hareketler gün geçtikçe kamusal alanda daha fazla görünür olmuştur. Küresel ısınma, iklim krizi, hayvan hakları, doğal kaynaklar, dünyaya salınan zararlı gazların önlenmesi, yerelde HES'ler, bilinçsiz ve kontrolsüz maden aramaları, Nükleer santraller gibi konulara odaklanan çevre hareketleri, diğer yeni toplumsal hareket örneklerinde olduğu gibi günümüzün temel aktörleri haline gelmiştir.

Yeni toplumsal hareketler kapsamında çevreci hareketleri vurgulayan Giddens'a (1998: 952) göre, bu hareketler ayrıcalıksız insanların yaşam standardını değiștirmiştir. Daha doğrusu yeni dünyanın yeni aktörleri olarak yeni toplumsal hareket katılımcllarının vurguladığı kentsel sorunlar, barınma, hava kirliliğinin önlenmesi, parkların ve yeşil alanların korunması, bölgelerin doğasını değiştiren inşaat projelerinin durdurulması bu yaşam standardını değiştirecek gelişmeler olarak görülmelidir. Bu beklenti ve taleplerle yola çıkan bir dizi toplumsal hareket yakın dönemde çevreci hareketlere öncülük etmiştir. Bu hareketler günümüzde küresel ısınma, buzulların erimesi, deniz ve okyanusların tahribatı, hayvan türlerinin yok olması, ozon tabakasının delinmesi, ormanların tahribatı ve beraberinde tüm canlıların zarar görmesi, doğal kaynaklara yoğunlaşmış durumdadır. Bu konulara değinirken de çevre sorunlarının başlı başına çevreyle ilgili olmadığını, bunun artık küresel bir politika haline geldiğini vurgulamaktadırlar. Küresel sorun haline gelen çevre sorunlarının da uluslararası kuruluşlar ve tüm dünya devletlerinin desteğiyle değişebileceğini, yasal düzenlemelerle caydırıcı önlemler alınması gerektiği vurgulanmaktadır.

Küresel önlemlerin alınmaması nedeniyle artacak olan doğa olaylarının bedenlinin ağır olması kaçınılmazdır. Nitekim McGrath'e (2020) göre, 2020 yılından beri dünya çapında 10 büyük iklim olayı ortaya çıktı ve bunların 6 tanesi Çin ve Hindistan'ın olduğu kıtalarda yaşandı ve maddi zararı 40 milyar doları aştı. Aynı șekilde ABD’yi etkileyen kasırga ve orman yangınlarının 60 milyar dolar zarara neden olduğu vurgulanmıştır. Bunların yanı sıra, muson yağmurları ve seller, Afrika'daki çekirge istilası benzeri istilalar küresel iklim dengesinin bozulmasından kaynaklıdır. Bu doğa dengesinin ortaya çıkardığı maddi zararların ötesinde, bu olaylardan etkilenen ve hayatını kaybeden canlı türlerinin sayısı azımsanmayacak derecede büyüktür.

Küresel iklim krizinin daha fazla devam etmemesi adına yeni toplumsal hareketler dünya çapında acil eylem planları talep etmektedir. İnsanları gelecekte daha güvenli bir dünya taşımanın önemine değinen çevre hareketleri, BM İklim Zirvesi başta olmak üzere, devletleri acil önlem almaya davet ederken, çevre sorunlarına kendi güçleri çerçevesinde engel olma çabasındadır. Bu çabaların karşılık bulamaması durumunda küresel salgın hastalıkların da hayatımızın bir parçası olmaya devam edeceği üzerinde durulmaktadır. Nitekim son iki yıldır tüm dünyayı etkisi altına alan, sağlık sorunları başta olmak üzere, ekonomik ve sosyal sorunlara neden olan Covid-19 küresel salgını benzeri durumlarla karşılaşılmaması adına alınacak önlemlere yoğunlaşmak gerekmektedir. Çünkü küresel çevre sorunları sonuçları itibariyle, ekonomik, sosyal, siyasal etkiler yaratsa da dünya sağlığını etkileme bakımından da ciddiye alınması gereken bir durumdur.

\section{SONUÇ VE ÖNERÍLER}

Toplum durağan değil sürekli değişen ve dönüşen bir özelliğe sahiptir. Bu dönüşüm süreci modernleşme ile hız kazanmış olsa da küreselleşme ile üst boyuta ulaşmıştır. Küreselleşmenin toplum üzerindeki etkisi çok boyutlu olmuştur. Bu boyutlardan biri de toplumsal yapının değişmesi ve buna bağlı olarak toplumsal hareketlerin dönüşümü olmuştur. Küreselleşme döneminde yeni toplumsal sorunların ortaya çıkmasıyla klasik yaklaşımlar etkisini yitirmiştir. Buna bağlı olarak yeni toplumsal hareketler ortaya çıkmıştır. Küreselleşme sürecinde belirgin bir şekilde toplumsal muhalefet şekli olarak kamusal alanda görünürlük kazanan yeni toplumsal hareketler, küreselleşmenin olumsuz sonuçlarına odaklanmıştır. Savaş ve barıș, küresel silahlanma, insani güvenlik, küresel terör sorunu, nükleer tehditler, kimlik çatışmaları, tek tipleşme, özel hayatın denetlenmesi, ulus kimliklerin dönüşümü, tüketim kültürü, boş zaman değerlendirmesi, kimlik ve kültürlerin tek tipleştirilme çabaları, küresel şirketlerin doğal kaynakları özelleştirmesiyle yaşanan çevre 
sorunları küreselleșmenin olumsuz sonuçları kapsamında yeni toplumsal hareketlerin gündeminde olmuştur.

Küresel sorunlara odaklanan yeni toplumsal hareketler kimlik hareketi, küreselleşme karşıtı hareket, sistem karşıtı hareket, etnik ve dinsel hareket, dünya çapındaki kitlesel göç hareketi şeklinde gelişme göstermiş olsa da çalışmanın genelinde çevre duyarlılığı ve sorunlarına odaklanan çevre hareketleri ele alınmıştır. Bu hareketlerden bir kısmı da örnek olması açısından değerlendirilmiştir. Örneğin Greenpeace, milyonlarca destekçisiyle çevre sorunlarında etkili olan bir hareket olarak ele alınmıştır. Benzer etkileri yaratması bakımından Yeryüzü Dostları (Friends of the Earth-FoE) da aynı şekilde milyonlarca destekçisi olan uluslararası bir harekettir. Yine uluslararası bir çevre örgütü olan WWF'nin milyonlarca destekçisinin olması çevre sorunlarına olan duyarlılığın büyüdüğünü göstermiștir. Doğal kaynakların metalaştırılması, her şeyin paraya dönüştürülmesi ve çevrenin ihmal edilmesinin sonucunda, devletlerin gereken önlemi almamış olması bu konuda duyarlı olan çevre hareketlerinin ortaya çıkışını hızlandırmıştır.

Çevre sorunlarının görmezden gelinmesi ve yeterli önlemlerin alınmaması üzerinden başlayan tartışmanın aktörleri olarak çevre hareketleri izledikleri politikalarla 1970'lerden beri devlet politikaları üzerinde etki sahibi olmuştur. Touraine tarafından vurgulandığı üzere çevre hareketi, doğayı, yeryüzünü savunur; çevreyi bozanlara saldırır ve bir kalıcı gelişme fikrini, yani kendini duyurmak için hem zamanda hem de uzamda fazlasıyla uzakta olanların çıkarlarını savunmuştur. Bu çıkarları savunurken devlet politikaları üzerinde de etkili olmuştur. Nitekim uluslararası kuruluşların sera gazı yayılımını azaltmak, çevre kirliliğini engellemek ve küresel iklim krizinin önüne geçmek amacıyla imzaladıkları sözleşmeler bu gelişmelerin etkisiyle olmuştur. Bu sözleşmeler ve alınan önlemler üzerinde çevre hareketlerinin etkisi vardır. Ayrıca dünya genelinde artan çevre sorunlarının ciddi boyutlara ulaşmasından dolayı, AB, BM, OECD, AGITT gibi örgütlenmeler çevre hareketlerinin eylemlerine duyarsız kalamamıştır. Özellikle de küresel ısınmaya karşı uluslararası devletler tarafından yapılan Kyoto Protokolü'yle (1997) atmosferdeki sera gazının düşürülmesinin amaçlanması bu duyarlılık çerçevesinde gerçekleşmiş ve günümüze kadar da önemini korumuştur.

Siyasal partiler ile hükümet veya devletlerin, talepleri yerine getirme konusunda yetersizlikleri sonucunda yeni toplumsal hareketler daha fazla destek görmüştür. Bu desteği çevre hareketleri başta olmak üzere bütün hareketlerde görmek mümkündür. Ayrıca yeni toplumsal hareketlerin desteklenmesinin sebeplerinden biri devletler tarafından kısa vadede çözülemeyen sorunların, yeni toplumsal hareketlerin eylemleri sonucunda çözülmesinden dolayıdır. Bu kapsamda ele alınan yeni toplumsal hareketlerin bir örneği olarak çevre hareketleri çevre sorunlarına çözüm üretmesi, devlet politikaları üzerinde etkili olup değişimlere öncülük etmesi nedeniyle toplumsal destek görmüştür. Çünkü çevreci hareketler diğer parti veya bazı hareketlerden farklı olarak bütün kutuplaşmaların ötesine geçip, yeni bir dinamizm geliştirmiştir. Bu dinamizmle beraber destek artmıştır. Bu desteğin gelecekte de devam etmesi söz konusudur.

Sonuç olarak insan hakları ve çevre hakları başta olmak üzere, geleceğin tasarlanmasında başvurulacak gelişmeler yeni toplumsal hareketlerin taleplerinden bağımsız olamayacaktır. Ayrıca yeni toplumsal hareketler toplumsal desteğe sahip olması nedeniyle sivil toplum alanını genişletmektedir. Bu nedenle iklimle ilgili yapılacak düzenlemelerde yeni toplumsal hareketlerin desteğini alıp fikirlerini önemsemek daha evrensel ve kabul edilebilir gelişmelerin ortaya çıkmasını sağlayabilir. Buna ek olarak devletlerin çevre ve iklim konusunda yasal düzenlemeleri gözden geçirmeleri, küresel iklim değişikliği konusunda da daha radikal adımlar atması gerekmektedir. Örneğin 2016 yılında Ruanda'da taraf ülkelerin desteğiyle kabul edilen Kigali Değişikliği bu olumlu adımlardan biridir. Artık birçok ülkeye göre "iklim değişikliğinin olumsuz etkileri karşısında uyum faaliyetlerinin katılımcı ve kapsamlı bir yaklaşımla ele alınması gereklidir. Bu konuda uluslararası ve yerel ölçekte her bir paydaşın gerçekleştireceği çalışmalar bu mücadeleyi güçlendirecektir." Bu kapsamda iklim değişikliğinin etkilerinin daha asgari seviyeye indirilmesi için uluslararası bir mutabakatın gelecekte de sürdürülmesi çevre hareketlerinin de gündemindedir. 


\section{KAYNAKÇA}

Aslan, C. (2016). Sosyal Hareketler Sosyolojisi Toplumsal Fay Hatlarının Anatomisi. Adana: Karahan Kitabevi.

Bauman, Z. (2017). Küreselleşme. Çev. Abdullah Y., İstanbul: Ayrıntı Yayınları.

Betts, A. (2017). Zorunlu Göç ve Küresel Politika. Çev. Seher Meltem T., Ankara: Hece Yayınları.

Bıhl, J. (2016). Toplumsal Ekoloji Siyaseti. Çev. Esra E., İstanbul; Sümer Yayıncılık.

Castells, M. (2010). "The Greening of the Self: The Environmental Movement”, İçinde Rise of Network Society, 2, The Power of Identity Wilwy Blackwell, 168-191.

Chomsky, N. (2002). 11 Eylül ve Sonrası: Dünya Nereye Gidiyor?. Çev. Taylan Doğan Nuri E., Mehmet K., ve Ali K., İstanbul: Aram Yayınları.

Çayır, K. (2016). "Sunuş", İçinde Kenan Çayır (Edt.), Yeni Toplumsal Hareketler, İstanbul: Kaknüs Yayınları, 7-10.

Dede, A. (2018). Talepkar Bir Hareket Olarak Yeni Toplumsal Hareketler. İstanbul: Literatürk Academia.

Douzinas, C. (2017). Insan Hakları ve Imparatorluk. Çev. Kasım A. ve Rabia S., İstanbul: İstanbul Bilgi Üniversitesi Yayınları.

Durul, F. (2008). Küreselleşme ve İnsan Hakları. İstanbul: Toroslu Kitaplığı.

Galtung, J. (2013). Insan Hakları: Başka Bir Açıdan Bakış. Çev. Müge S., İstanbul: Metis Yayınları.

Giddens, A. (1998). Modernliğin Sonuçları. Çev. Ersin K., İstanbul: Ayrıntı Yayınları.

Hülür, H. (2000). "Küreselleşme ve Toplumbilimsel Kuramlaştırma Sorunu”, Selçuk İletişim Dergisi. 1(2), 27-36.

Kalouche, M., Fouad, E. (2008). "Sistem Karşıtı Hareketlerin Dönüşümü 1968-2005”, Çev. Deniz K., İçinde William G. Martin (Edt.), Toplumsal Hareketler 1750-2005, İstanbul: Versus Yayınları, 219-283.

Keskin, M. (2003). “Akkuyu Çernobil Olmadı”, İçinde Leyla S.,Toplumsal Hareketler Konuşuyor, İstanbul: Alan Yayıncılık, 95-118.

Kömeçoğlu, U. (2002). “Küreselleşme, Modernleşme, Modernlik”, Doğu Batı Dergisi, 18, 11-28.

Mavi, İ. (2021). Küreselleşme Bağlamında Yeni Toplumsal Hareketler; Barış ve İnsan Hakları Hareketi, (Yayınlanmamış) Doktora Tezi, Kırıkkale: Kırıkkale ÜniversitesiSosyal Bilimler Enstitüsü.

McGrath, M. (2020). “2020'de Küresel Isınmaya Bağlı Aşırı Doğa Olaylarının Bedeli Çok Ağır Oldu”, BBC News, mhttps://www.bbc.com/turkce/haberler-dunya-55468310., 29.12.2020.

Mcluhan, M. (2001). The Global Village: Transformations in World Life and Media in the 21st Century. U.S.A. : Oxford University Press.

Offe, C. (2016). "Yeni Sosyal Hareketler: Kurumsal Politikanın Sınırlarının Zorlanması", İçinde Kenan Çayır (Edt.), Yeni Sosyal Hareketler, İstanbul: Kaknüs Yayınları, 47-74.

Onbaşı, F. (2019). “Toplumsal Hareketler, Siyasal Teoriler”, Birikim Dergisi, 368, 18-28.

Robertson, R. (1999). Küreselleşme, Toplum Kuramı ve Küresel Kültür. Çev. Ümit Hüsrev Y., Ankara: Bilim Sanat Yayınları.

"Australia Bushfires: Towns Devastated And Lives Lost As Blazes Turn The Sky Red”, (2020). The Guardian, https://www.theguardian.com/australia-news/live/2020/jan/01/australia-bushfires-newsouth-wales-victoria-fires-news-latest-live-updates., 01.01.2020.

Touraine, A. (2007). Bugünün Dünyasını Anlamak İçin Yeni Bir Paradigma. Çev. Olcay K., İstanbul: Yapı Kredi Yayınları.

Uysal, A. (2016). Toplumsal Hareketler Sosyolojisi. İstanbul: Tezkire Yayınları.

Wallerstein, I. (2009). Tarihsel Kapitalizm. Çev. Necmiye A., İstanbul: Metis Yayınları.

Araştırmacının Katkı Oranı Beyanı: Bu makalenin tek yazarıyım. Tamamı tarafımca hazırlanmıștır.

Çıkar Çatışması Beyanı: Bu çalışmada potansiyel bir çıkar çatışması yoktur. 